\title{
Physicochemical Characteristics Identification and Secondary Metabolite Analysis of Solid Herbal Waste as Source of Feed Rich Fiber and Supplement for Ruminants
}

\author{
Arif Nindyo Kisworo ${ }^{1)^{*}}$, Ali Agus²), Kustantinah²), Bambang Suwignyo²) \\ 1)Bogor College of Agriculture Extension, Bogor, Indonesia \\ 2)Department of Feed and Nutrition, Faculty of Animal Science, University of Gadjah Mada, Yogyakarta, 55281 \\ *Corresponding author email: arifnindyo@yahoo.co.id
}

\begin{abstract}
A study was conducted to determine the potency, physicochemical characteristics, and to analyze the secondary metabolites content of solid herbal waste (SWH) as a substitute source of feed rich fibre and feed supplements in ruminants. The first study included an analysis of production potential, physical analysis, and chemical composition analysis of SWH. The second study was an analysis of secondary metabolites content of SWH. The results showed that SWH volume reached 6-8 m3/day or 4020-5360 kg/day, the chemical composition of herbal solid waste was similar to king grass with high lignin content (17.53\%). SWH containing total phenols, flavonoids, tannins, saponins, alkaloids and essential oils which generally have antimicrobial activity. According to the potential availability, chemical composition and secondary metabolites content of SWH, it can be used as an alternative for substitute of feed rich fiber or feed supplements with attention to the content of secondary metabolites that can affect the process of fermentation and digestibility in the rumen. Further in vitro and in vivo research ore needed to determine the effect of SWH on rumen fermentation parameters and its application in the ration in ruminant livestock.
\end{abstract}

Key words : Solid herbal waste, feed rich fiber, plant secondary metabolites, antimicrobial activities, rumen fermentation

Abstrak. Penelitian ini bertujuan untuk mengetahui potensi dan karakteristik fisikokimia limbah padat jamu (LPJ) dan melakukan analisis kandungan metabolit sekunder LPJ sebagai pengganti pakan sumber serat dan suplemen pakan pada ternak ruminansia. Penelitian pertama meliputi analisis potensi produksi, analisis fisik, dan analisis komposisi kimia limbah padat jamu. Penelitian kedua adalah analisis kadar metabolit sekunder LPJ. Hasil penelitian menunjukkan volume LPJ mencapai $6-8 \mathrm{~m} 3 / \mathrm{hari}$ atau $4.020-5.360 \mathrm{~kg} / \mathrm{hari}$, komposisi kimia limbah padat jamu mendekati rumput raja dengan kandungan lignin yang tinggi $(17,53 \%)$, LPJ mengandung total fenol, flavonoid, tanin, saponin, alkaloid dan minyak atsiri yang secara umum memiliki efek antimikrobia. Melihat potensi ketersediaan limbah, komposisi kimia dan kandungan metabolit sekundernya, LPJ dapat digunakan sebagai alternatif bahan pakan pengganti serat atau suplemen pakan dengan perhatian terhadap kandungan metabolit sekunder yang dapat mempengaruhi proses fermentasi dan kecernaan di dalam rumen, sehingga diperlukan penelitian lebih lanjut pengaruh LPJ terhadap parameter fermentasi rumen dan aplikasinya dalam ransum pada ternak ruminansia.

Kata kunci: Limbah padat jamu, pakan sumber serat, metabolit sekunder tanaman, efek antimikrobia, fermentasi rumen

\section{Introduction}

One potential feed source from industrial waste that can be developed in Java Island but still limitless researched is the solid waste produced from herbal medicinal industry. Industrial waste or residual dregs herbal medicine is extracted from various parts of herbs either the leaves, stems, bark, fruit, seeds, and roots or rhizomes. The parts of this plant suspected to be the source of fibrous feed or animal feed supplements because they still contain nutrients such as carbohydrates, protein, crude fiber and various bio-active of plant secondary metabolites that can affect the digestion and performance of ruminants.

Solid herbal waste samples used in this study was a waste from medicinal products Antangin ${ }^{\circledR}$ containing residues of the roots or rhizomes, stems and leaves of the herb which composed 
of mint plant (Mentha piperita), sembung (Blumea balsamivera) and ginger (Zingiber oficinale).

In general, extracts of herbs not only contain one kind of secondary metabolites, but could be dozens or even hundreds of secondary metabolites of some kinds of structural group, so that the effect of the herb can be an interaction of a wide variety of secondary metabolites that can not be detected if only one kind of metabolites is evaluated (Wink, 2015). Therefore, it is necessary to study the chemical composition of solid waste herbal medicine, including the content of secondary metabolites, suspected to be contained therein. The objective of this study was to evaluate the solid waste herbal medicine as an alternative to animal feed in terms of its constituent components, nutritional value and plant secondary metabolites content.

\section{Materials and Method}

Fresh herbs solid waste sample for physical analysis was taken from solid herbal waste disposal sites of PT. Deltomed Laboratories. Sample collected five times. Each sample in five

\section{Research procedures}

Sample of fresh herbs solid waste was taken from the PT. Deltomed Laboratories waste tank in five points at random each weighing of 1000 grams. Samples were kept in a box then taken to the laboratory of Animal Feed Science for analysis. Sampling was performed five times with an interval of two weeks. Examples of each solid waste sample was taken as much as 1000 grams with two replications, then the constituent parts were separated included leaves, stems, seeds, roots, rhizomes and crumbs / dirt. Furthermore, each part of these solid herbal waste constituent was weighed and the percentage was calculated. The characteristics of $\mathrm{pH}$, density, odor, and color of solid waste herbal medicine were recorded. Data were tabulated and analyzed descriptively.
Dry matter (DM), Organic Matter (BO), Crude Protein ( $C P ; N \times 6.25$ ) and Ether Extract (EE) of solid herbal waste were determined by proximate analysis (Wendee) according to AOAC (2005). Neutral detergent fiber (NDF), acid detergent fiber (ADF) and lignin were analyzed by the method of Goering and Van Soest (1970). Ca and $P$ were analyzed by spectrophotometer according to AOAC methods (2005).

Total saponins and phenols were analyzed using procedures of Stahl (1985) and the method of Chanwitheesuk et al. (2005). Flavonoids were analyzed by spectrophotometry UV-Vis methods according to Farmakope Herbal Indonesia (Departemen Kesehatan RI, 2008). Total tannin content was analyzed by subtraction amount of polyvinylpolypyrrolidone that bind with tannin and acid equation expressed in tannin (tannic acid equivalents) (Makkar et al., 1993). Alkaloid content was measured using a spectrophotometer at a wavelength of $420 \mathrm{~nm}$. Essential oils measured using maceration method according to Materia Medica Indonesia (Departemen Kesehatan RI, 1995).

\section{Observation variable}

Physical analysis observation variable of SWH include the composition of the leaves, stems, seeds, roots, rhizomes and crumbs/dirt. The characteristics of $\mathrm{pH}$, odor, color and density (BJ) also notes. Variable observations of chemical composition SWH was Dry Matter (DM), Organic Matter (OM), Crude Protein (CP; $\mathrm{N} \times$ 6.25) and Ether Extract (EE), Neutral detergent fiber (NDF), acid detergent fiber $(\mathrm{ADF})$, lignin, $\mathrm{Ca}, \mathrm{P}$, and secondary metabolites of SWH (total phenols, total tannins, flavonoids, saponins, alkaloids and essential oils).

\section{Data analysis}

Physical characteristics, chemical composition, and SWH secondary metabolites content were tabulated and analyzed descriptively (Steel and Torrie, 1995). 


\section{Results and Discussion}

\section{Physical caractheristic evaluation of solid herbal waste}

PT. Deltomed produce some instant herbal medicines. According to the catalog of products from PT. Deltomed Laboratories, Tbk. The main components of Antangin $^{\circledR}$ instant herbal medicine composed of ginger extract (Zingiber oficinale), mint (Mentha piperita), sembung (Blumea balsamivera), and panax ginseng, while the minor components were rhizome extract of Curcumae domestika, Myristicae cement and Glycyrrhizae radix (Deltomed, 2015). The composition of these plants in herbal medicine has been standardized. Samples for physical characteristics analysis was taken from the waste container vessel in five replication with an interval of two weeks. Solid waste constituent parts of these plant herbs were weighed and the percentage was calculated. The percentage of medicinal plant parts constituent of solid waste is presented in Table 1.

The components of solid waste plant herbs in this study are fine roots, rhizomes, stems and leaves, stems and roots, bark, seeds, and plant crumbs. Fine roots and rhizomes comprises $76.56 \%$, other plant parts such as stems and leaves, stems and roots, bark, and fruit and seed is only only $5.8 \%$, while the unidentified crumbs parts of the plant is $17.64 \%$.

Medicinal herbal plants was extracted using water at high temperatures, around $70-80$ - $\mathrm{C}$ to obtain the extract. The boiling process at high temperatures allegedly can break or loosen lignocellulose ties in plants herbs. Effect of extraction of herbal plants with high temperature is thought to resemble the steaming process to increase the digestibility of fibrous feed ingredients such as rice or wheat straw. Research conducted by Viola et al. (2008) to improving the digestibility of wheat straw, barley, and oats showed using water heating at a temperature of $1980 \mathrm{C}$ for 2.5 minutes (steam explosion) can improve the digestibility of straw up to $25 \%$.

Table 1. Parts of herb plants / 1000 grams of Solid Waste Herb

\begin{tabular}{lrc}
\hline \multicolumn{1}{c}{ Parts of Plant } & \multicolumn{1}{c}{ Sample } & Persentage \\
\hline Fine roots & $598.2 \pm 107.70$ & $60.79 \%$ \\
Rhizome & $155.2 \pm 45.54$ & $15.77 \%$ \\
Stems and leaves & $32.6 \pm 35.12$ & $3.31 \%$ \\
Leather trunk & $14 \pm 19.00$ & $1.44 \%$ \\
Stems and roots & $6.8 \pm 9.55$ & $0.69 \%$ \\
Fruit and seed & $3.4 \pm 4.67$ & $0.35 \%$ \\
Mix crumbs & $173.6 \pm 54.76$ & $17.64 \%$ \\
\hline Total & $984 \pm 38.29$ & $100.00 \%$ \\
\hline
\end{tabular}

Allegedly, warming effect will also result in denaturation, coagulation and non-enzymatic browning process proteins in solid waste herbal medicine. Protein denaturation occurs when heated at a temperature of $60-90 \circ \mathrm{C}$ for approximately 1 hour. Denaturation reaction could not break the peptide bond so the primary structure of the protein molecule is not damaged (Winarno, 2006). It made protein denaturation easy to settle and digest by proteolytic enzymes (Winarno, 1997). Coagulation is defined as one that occurs as a result of proteins damage and clotting heating and hardening of the protein as it absorbs the water in the process (Makfoeld, 2008). Protein will undergo coagulation when heated at a temperature of $50^{\circ} \mathrm{C}$ or more. Coagulation occurs only when the protein is in iso electric point, at which point the protein is soluble at a $\mathrm{pH}$ in the outer of iso electric points (Purwaningsih, 2007). Browning process is the process of yellow pigment formation which will soon turn into dark brown. The formation of a brown color is triggered by oxidation reaction catalyzed by the phenol oxide or polyphenol oxide enzyme (Makfoeld, 2008).

Samples of solid herbal waste have an average density of $0.67 \pm 0.14 \mathrm{~kg} / \mathrm{l}$, with typical herbal bitter smell, greenish brown to dark brown color, and the average water content was $77.37 \%$. The density under 1.0 shows that 
Table 2. Gravity (BJ), odor and solid waste color

\begin{tabular}{cccccc}
\hline Sample & $\begin{array}{c}\text { Volume } \\
\text { (liters) }\end{array}$ & Wheight $(\mathrm{kg})$ & BJ (kg/lter) & Odor & Color \\
\hline 1 & 1.00 & 0.53 & 0.53 & Bitter herbs typical & Brown \\
2 & 1.00 & 0.56 & 0.56 & Leaves smell, herbs & Greenish brown \\
3 & 1.00 & 0.84 & 0.84 & Herbs typical odor & Brown \\
4 & 1.00 & 0.79 & 0.79 & Bitter herbs typical & Dark brown \\
5 & 1.00 & 0.61 & 0.61 & Herbs typical odor & Brown \\
\hline
\end{tabular}

the mass of solid herbal waste is lighter than water mass so it will float. This solid waste is bulky that it will not solidify when placed in a container.

Bitter and pungent odor of solid waste medicinal herbs thought to have come from the content of plant secondary metabolites remaining in the effluent herbs such as alkaloids, glycosides (saponins), flavonoids, phenols, tannins, terpenes and essential oils (Dharmananda, 2010).

The brownish color of solid waste herbal medicine due to the original color of the herbal plant parts such as roots and branches, or allegedly because protein browning reaction. Browning process is divided into two parts, enzymatic browning and non-enzymatic browning process. Non Enzymatic Browning consists of three kinds reaction, Maillard reaction, caramelization and browning due to vitamin C (Makfoeld, 2008).

Enzymatic browning may occur because the total amount of phenols contained in solid waste herbal medicine. According to Makfoeld (2008) browning reactions are common in fruits and vegetables such as bananas, peaches, bark, nutmeg, strawberries, and apples that have phenolic compounds. The formation of a brown color is triggered by oksidation reaction catalyzed by phenol oxidase or polyphenol oxidase enzyme. Both of these enzymes can catalyze the oxidation of phenolic compounds into Quinon and then dipolimerize to be melaniadin brown pigment.
The chemical composition and content of secondary metabolites of solid herbal waste

Compared to some feed rich fiber that generally used as ruminant feed such as king grass, rice straw, corn stalks, and banana stems, solid herbal waste in this study had a higher crude protein content, while the fiber and fat were relatively equal except banana stems.

Solid herbal waste in this study has higher content of ash, ADF, lignin, $C a$ and $P$, and lower content of ETN, NDF, hemicellulose and silica compared to king grass. The high fiber and low protein content in solid herbal waste resembling to king grass, besides solid herbal waste also comes from various parts of the plant, so that solid herbal waste could be used as alternative feed sources for fibers substitute mainly grass forage. However the low content of ETN and high content of ADF on solid waste herbal medicine, indicates the low water soluble carbohydrates (non-structural carbs) and higher structurally carbohydrates than the king grass so the level of digestibility waste solid herbs will be relatively lower than king grass. Lignin content of solid waste herbal medicine is also relatively high, reaching $17.53 \%$.

Lignin is a part of the plant that cannot be digested by anaerobic rumen microbes, most likely because of the low oxygen content and the structure of the condensed lignin that blocking hydrolysis, while the anaerobic microbes in the rumen also can't produce lignolitic enzymes. 
Table 3. Comparison of the chemical composition of the Solid herbal waste, king grass (Pennisetum hybrid), corn, rice and banana stems.

\begin{tabular}{|c|c|c|c|c|c|}
\hline Parameter & $\begin{array}{l}\text { Solid herbal } \\
\text { waste }\end{array}$ & King Grass & Corn ${ }^{b c}$ & Rice $^{\text {bd }}$ & $\begin{array}{l}\text { Banana } \\
\text { Stems }^{b}\end{array}$ \\
\hline BK (\%) & 22.73 & 18 & 20 & 40 & 10 \\
\hline PK (\%) & 10.82 & 9.1 & 5.5 & 4.3 & 3.9 \\
\hline SK (\%) & 33.75 & 33.1 & 29.6 & 33.8 & 24.0 \\
\hline LK (\%) & 2.61 & 2.3 & 2.0 & 2.5 & 2.0 \\
\hline ETN (\%) & 33.33 & 40 & 55.3 & 35 & 56.1 \\
\hline Abu (\%) & 19.54 & 15.4 & 7.5 & 24.5 & 14.0 \\
\hline TDN (\%) & 52 & 55 & 60 & 49 & 60 \\
\hline NDF (\%) & 65.15 & 73.80 & - & - & - \\
\hline Hemiselulosa (\%) & 13.4 & 26.90 & - & - & - \\
\hline ADF (\%) & 51.75 & 42.36 & - & - & - \\
\hline Selulosa (\%) & 32.26 & 38.63 & - & - & - \\
\hline Lignin (\%) & 17.53 & 5.43 & - & - & - \\
\hline Si (\%) & 1.96 & 4.9 & - & - & \\
\hline $\mathrm{Ca}(\%)$ & 0.78 & 0.51 & 0.6 & - & 0.35 \\
\hline $\mathrm{P}(\%)$ & 0.82 & 0.51 & 0.1 & - & 0.08 \\
\hline Energi Bruto (Kcal) & $3988 \mathrm{kcal}$ & - & - & - & - \\
\hline DE (Kcal/kg) & $2293^{a}$ & 2420 & 2640 & 2150 & 2630 \\
\hline
\end{tabular}

The large amount of cellulose that can be degraded in the rumen, especially depending on the degree of the plant material lignifikation (McDonald et al., 2002). The lignocellulose structure is very tight and strong making it difficult for microbial enzymes to break down cellulose and hemicellulose into simple sugars (Chahal and Chahal, 1998).

Cellulose crystalline structure is very dense and difficult to be broken down by enzymes produced by rumen microbes. Hydrogen bonding between cellulose molecules and straight and flat hydrophobic bonding on the top surface and bottom layers of cellulose, causing van der Waals interactions between cellulose layers to forming the unity between the strands of cellulose that is very stable and difficult to dissolve (Brandt et al., 2013).

The high content of lignin expected to affect the digestibility of solid herbal waste, but plant herbal medicine has been boiling at $80^{\circ} \mathrm{C}$ in the extraction process, so that the alleged structure of lignocellulose and crystalin cellulose bonding portion has been disconnected or become more tenuous thus allowing crude fiber digesting enzymes to entrance and digest cellulose and hemicellulose.

When compared with other agricultural waste that are widely available in Indonesia, the solid waste herbal medicine has an advantage in terms of their chemical composition. The protein content of solid waste herbal approximately $10.8 \%$ while sorghum straw $3.8 \%$, banana stems $3.9 \%$, peel and pineapple fruit axis 3.4\% (Hartadi et al., 2005), and cocoa pod husks 9.7\% (Zain, 2009), in addition, the lignin content of solid waste herbal medicine is lower than the pod husks (20.15\%) (Zain, 2009).

The existence of plant secondary metabolites in solid waste air herbs are still relatively high, although in general the typical bitter smell of herbs had been reduced. It was shown from the results of solid herbal waste secondary metabolites analysis in Table 4.

Analysis of the six types of secondary metabolites expected in solid waste herbal 
medicine showed positive results. Plant secondary metabolites levels from the highest to the low were tannins, phenols, saponins, alkaloids, flavonoids and essential oils. These solid herbal waste are known mainly composed of mint plant (Mentha piperita), sembung (Blumea balsamivera), ginger (Zingiber oficinale) and Panax ginseng (Deltomed, 2015). The literature study shows ginger, mint, and sembung containing more than one secondary metabolites (Table 5). The accumulation of a variety of plant secondary metabolites is thought to cause the levels of several types of secondary metabolites such as total phenols, flavonoids, tannins, saponins and alkaloids is quite high, although it has undergone a solvent extraction process using water at about $80^{\circ} \mathrm{C}$.

Plant secondary metabolites have different mode of action and an effect depending on their chemical structure in which each has a reactive functional group (Wink, 2015).

Plants secondary metabolites are often characterized as both poisonous and medicinal, and a beneficial or an adverse result may depend on the amount eaten and the context of intake (Bernhoft, 2010). Polyphenol compounds commonly found in plants, both nutrients or non-nutrients. Polyphenols are known to have antioxidant potential in vitro (Kahkonen et al., 2003). Polyphenols are compounds that are biologically active as it can donate hydrogen atoms to free radicals and can prevent lipid oxidation chain reaction at the beginning of the initiation phase (Gulcin et al., 2004). Simple phenols, phenolic acids, coumarin, tannins and flavonoids are part of polyphenol compounds (Kahkonen et al., 2003). Flavonoids are the largest group of plant secondary metabolites in phenol class (Patra, 2012).

Flavonoids are known to have antibacterial, anti-fungal and anti-virus activity (Edziri et al., 2012; Andrew et al., 2009), antioxidants (Patra, 2012; Harborne, 1973), anti-inflammatory and analgesic effects (Harborne, 1973). In general flavonoids react against microbes by inhibiting microbial cytoplasmic membrane function, inhibits bacterial cell wall synthesis, or inhibit the synthesis of nucleic acids (Chusnie and Lamb, 2011).

Table 4 . Plant secondary metabolites content of solid herbal waste.

\begin{tabular}{llccccc}
\hline \multirow{2}{*}{ Forms } & \multicolumn{7}{c}{ Plant secondary metabolites (\%) } \\
\cline { 2 - 8 } & Total & Flavonoids & Tanins & Saponins & Alkaloids & EO \\
\hline FDSHW & 4,71 & 1,86 & 11,50 & 3,28 & 3,44 & 0,21 \\
\hline FDSHW & $=$ Freeze dried solid herbal waste & & & & \\
EO & $=$ Essential oils
\end{tabular}

Table 5. The presence of plant secondary metabolites in herbal medicinal plants constituent of solid herbal waste.

\begin{tabular}{lcccccc}
\hline \multirow{2}{*}{ Herbal plants } & \multicolumn{5}{c}{ Plant secondary metabolites ingridients } \\
& Phenol & Flavonoids & Tanins & Saponins & Alkaloids & EO* \\
\hline Blumea balsamifera & $+^{\mathrm{a}}$ & $+^{\mathrm{a}}$ & $+^{\mathrm{bc}}$ & - & $+^{\mathrm{c}}$ & $+^{\mathrm{c}}$ \\
Mentha pipperita & $+^{\mathrm{ef}}$ & $+^{\mathrm{e}}$ & $+^{\mathrm{d}}$ & $+^{\mathrm{de}}$ & $+^{\mathrm{de}}$ & $+^{\mathrm{de}}$ \\
Zingiber officinale & $+^{\mathrm{g}}$ & $+^{\mathrm{k}}$ & $+^{\mathrm{h}}$ & $+^{\mathrm{i}}$ & $+^{\mathrm{l}}$ & $+^{\mathrm{j}}$
\end{tabular}

* = essensial oils, + = exist, - = nonexist, a = Xu et al. (2013); N.Saewan et al. (2011); Nessa et al. (2004), b = Susiarti (2000), c = Dalimartha (1999); Hariana (2013); Bhuiyan et al. (2009), d = Schuhmacher (2013), e = Adham (2015), $f=$ Riahi et al. (2013), $g$ = Wolmuth et al. (2005); Mishra (2009); suryani (2012), $h=$ Ajayi et al. (2013), i = Nwinuka et al. (2005), j = Govindarajan (1982); Eze dan Agbo (2011), k = Ghazsemzadeh et al. (2010), I = Raaof et al. (2013). 
Tannins are polyphenols compounds that dissolve in water with a molecular weight of 500 - 5000 and has the ability to bind alkaloids, gelatin and other proteins (Ramakhrishnan and Krishnan, 1994), because it has a large number of hydroxy phenolic (Patra et al., 2012). Tannins are classified into two groups, namely hydrolyzed tannins and condensed tannins (Patra et al., 2012). Hydrolized tannins are easy for chemical hydrolyzation by rumen microbes enzyme to the form of phenolic compounds that can be absorbed by the bloodstream. While condensed tannins cannot be degraded by rumen microbial and will bind with fiber and protein fractions in the gastro intestinal tract. Condensed tannins are not absorbed in the bloodstream, resulting in normal physiological conditions that will not damage organs such as the liver and spleen (Makkar, 2003). Tannins bind proteins with hydrogen bonds which are sensitive to $\mathrm{pH}$ changes. Condensed tannins will bind stable at $\mathrm{pH}$ 4-7 in the rumen, whereas at extremes $\mathrm{pH}$, tannins-proteins bond will be separated, ie at a pH of less than 3 , in abomasum (El-Wazyri et al., 2005) and at pH of more than 7 in the intestine (Perez-Maldonado et al., 1995; Diaz-Hernandez et al., 1997 cit. Andrabi, 2005). Tannin also can bind and reduced cellulose degradations by rumen microbs (Klita et al., 1996). According to Min et al. (2005) the ideal tannin levels in the ration is 2-4\% of DM, tannin levels between $4-9 \%$ of DM is already too high. The high levels of tannin in forage can be reduced by wilting and drying under the sunlight (Kustantinah et al., 2005). Saponins have the ability to lyse protozoa in the rumen (Wallace et al., 1994). Saponins react against protozoa membrane sterols, particularly cholesterol (Glauert et al., 1962). The addition of saponin extract decrease protozoa population and increase the flow of lactic acid and microbial protein from the rumen to the small intestine (Wallace et al., 1994). A decreased ruminal ciliate protozoa population may enhance the flow of microbial $\mathrm{N}$ from the rumen, increase efficiency of $\mathrm{N}$ utilisation (Newbold et al., 1995). When amount of protozoa in the rumen pressed, there will be an increase in rumen bacteria that are a source of protein for ruminants. This resulted in the intake of protein to ruminant increasing performance. Alkaloids are nitrogen-containing compounds with a carbon skeleton showing the isoprenoid derived compounds. The most important members of this group are akonitum alkaloid and steroid alkaloids, and among these alkaloid compounds there serves as antifungus and insect repellent (Robinson, 1995). Furthermore in general it is believed that the alkaloid compounds cause a bitter taste. Feeding contains the alkaloid compounds in ruminant livestock can negatively impact the quality of the meat. For example the provision of papaya leaves contain alkaloids carpain in goats bligon feed cause bitter taste in meat, liver and lungs (Robinson, 1995; Harris, 2005). Alkaloids are known to have antibacterial activity, anti-virus, and together improve the antibiotics effect (Cushnie et al., 2014). The mechanism of action as an anti-bacterial alkaloids vary widely, depending on the chemical structure or class. For example, alkalod indolizidine class like pergularinine and tylophorinidine inhibits bacterial nucleic acid synthesis, by blocking the action of the enzyme dihydrofolate reductase (Rao and Venkatachalam, 2000). benzophenanthridine and protoberberine isoquinolines, the class of isoquinoline alkaloid, react by disturbing ring- $Z$ and inhibit cell division of bacteria (Cushnie et al., 2014), while phenanthridine isoquinoline ungeremine alkaloids react by inhibiting the synthesis of nucleic acids by interrupting the enzyme type I topoisomerase (Casu et al. , 2011). Essential oils (EO) is a mixture of secondary metabolites from herbal, spices, and aromatic plants that give its smell characteristic (Ultee et al., 1999). Essential oils have antimicrobial properties, by affecting the bacterial cell membrane (Ultee et al., 1999), 
deactivated bacteria enzymes (Benchaar and Henry, 2011), or inhibit microbial growth indirectly by causing bacterial cells lose much energy (Griffin et al ., 1999; Ultee et al., 1999). Essential oils can inhibit the growth of methaneogenic bacteria. Variations of essential oil components include phenolic compounds and aldehydes, intervere the ion transport in the cytoplasmic membrane and deactivated microbial enzymes (Benchaar and Henry, 2011).

\section{Conclusions}

Solid herbal waste contains a variety of plant secondary metabolites that have antimicrobial effects and binding protein and carbohydrates. According to the potential availability of solid waste and chemical composition, solid waste herbal medicine can be used as an alternative of feed ingredients to substitute feed rich fibers with attention to the content of secondary metabolites that could be expected to affect the process of fermentation and digestibility in the rumen.

\section{References}

Adham, AN. 2015. Comparative extraction methods, phytochemical constituents, fluorescence analysis and HPLC validation of rosmarinic acid content in Mentha piperita, Mentha longifolia and Osimum basilicum. Journal of Pharmacognosy and Phytochemistry. 3(6):130139.

Ajayi, OB, SF Akomolafe, and FT Akinyemi. 2013. Food Value of Two Varieties of Ginger (Zingiber officinale) Commonly Consumed in Nigeria. Hindawi Publishing Corporation. ISRN Nutrition Volume $2013 \quad$ (2013) : 1 - 5. http://dx.doi.org/10.5402/2013/359727. (accessed on $18^{\text {th }}$ April 2015).

Andrabi SM, MM Ritchie, C. Stimson, A Horadagoda, M Hyde, and DM McNeill. 2005. In vivo assessment of the ability of condensed tannins to interfere with the digestibility of plant protein in sheep. Anim. Feed Sci. and Tech. 122:13-27.

Andres A, SM Donovan, and TB Kuhlenschmidt. 2009. Soy isoflavones and virus infections. J. Nutr. Biochem. 20:563-569.

AOAC. 2005. Official Methods of Analysis. $13^{\text {th }} \mathrm{Ed}$. Washington DC: Association of the Official Analytical Chemist.
Benchaar C and G Henry. 2011. Essential oils and opportunities to mitigate enteric methanee emmisions from ruminants. Anim. Feed Sci. and Tech. 166-167:338-355.

Bernhoft A. 2010. A brief review on bio-active compounds in plants. In: Bio-active compounds in plants - benefits and risks for man and animals. Editor : Aksel Bernhoft. Proceedings. The Norwegian Academy of Science and Letters, Oslo. $\begin{array}{llll}\text { Pp: } & 11 & - & 17 .\end{array}$ http://www.dnva.no/binfil/download.php?tid=4 8677 (Diakses pada tanggal 1 Oktober 2015).

Bhuiyan MNI, JU Chowdhury, and J Begum. 2009. Chemical components in volatil oil fram Blumea balsamifera (L.) DC. Short Comunication. Bangladesh J. Bot. 38(1): 107 - 109.

Brandt A, J Gräsvik, JP Hallett, and T Welton. 2013. Deconstruction of lignocellulosic biomass with ionic liquids. Green Chem.15 (3): 537 - 848. http://pubs.rsc.org/en/ content/articlepdf/2013/GC/C2GC36364J. (Accessed on $12^{\text {th }}$ May 2015).

Casu L, F Cottiglia, M Leonti, A De Logu, E Agus, and YC Tse-Dinh. 2011. Ungeremine effectively targets mammalian as well as bacterial type I and type II topoisomerases. Bioorg. Med. Chem. Lett. 21: $7041-7044$

Chahal PS and DS Chahal. 1998. Lignocellulosic Waste: Biological Conversion. In: Martin, A.M. (eds). Bioconversion of Waste Materials to Industrial Products. Second Ed. Blackie Academic and Professional, London.

Chanwitheesuk A, A Teerawutgulrag, and N Rakariyatham. 2005. Screening of antioxidant activity and antioxidant compounds of some edible plants of Thailand. Food Chemistry. 92: 491-497.

Cushnie TPT, B Cushnie, and AJ Lamb. 2014. Alkaloids : An overview of their antibacterial, antibiotic-enhancing and antivirulence activities. International Journal of Antimicrobial Agents 44: $377-386$.

Cushnie TPT and AJ Lamb. 2011. Recent advances in understanding the antibacterial properties of flavonoids. International Journal of Antimicrobial Agents. 38 (2): $99-107$.

Dalimartha S. 1999. Atlas Tumbuhan Herbal Indonesia I. Trubus Agriwidya, Jakarta.

Deltomed Tbk, PT. 2015. Ingridients. In: Get Rid of Flu. PT. Deltomed Tbk. http://www.antangin.com/home.php. (Accessed on $11^{\text {th }}$ January 2016).

Departemen Kesehatan RI. 2008. Farmakope Herbal Indonesia Edisi I. Departemen Kesehatan Republik Indonesia. 
Departemen Kesehatan RI.1995. Materia Medika Indonesia Jilid VI. Departemen Kesehatan Republik Indonesia.

Dharmananda S. 2010. Taste and Action of Chinese Herbs, Traditional and Modern Viewpoints. Institute for Traditional Medicine, Oregon. http://www.itmonline.org /articles/taste_action/taste_action_herbs.htm. (Accessed on $11^{\text {th }}$ January 2016).

Edziri H, M Mastouri, MA Mahjoub, Z Mighri, A Mahjoub and L Verschaeve. 2012. Antibacterial, Antifungal and Cytotoxic Activities of Two Flavonoids from Retama raetam Flowers. Molecules. 17:7284-7293. www.mdpi.com /1420-3049/17/6/7284/pdf. (Accessed on $1^{\text {st }}$ January 2016)

El-Wazyri AM, MEA Nasser, and SMA Sallam. 2005. Processing methodes of soybean meal : 1-effect of roasting and tannic acid treated-soybean meal on gas production and rumen fermentation in vitro. J. of Appl. Sci. Research. 1(3):313 - 320.

Eze JI and KE Agbo. 2011. Comparative studies of sun and solar drying of peeled and unpeeled ginger. Am. J. Sci. Ind. Res. 2:136-143.

Ghasemzadeh A, Jaafar HZ, and Rahmat. 2010. Identification and concentration of some flavonoid components in Malaysian young ginger (Zingiber officinale Roscoe) varieties by a high performance liquid chromatography method. Molecules. 15(9):6231-43.

Glauert AM, JT Dingle, and JA Lucy. 1962. Action of saponin on biological membranes. Nature. 196:953-955.

Goering HK And PJ Van Soest. 1970. Forage Fiber Analysis (apparatus, reagent, procedures and some applications). Agric. Handbook b379, ARS, USDA, Washington D.C.

Govindarajan V. 1982. Ginger-chemistry, technology and quality evaluation: Part I. CRC. Crit Reviews in Food Science and Nutrition. 19: 1 - 96.

Griffin SG, SG Wyllie, J.L. Markham, and D.N. Leach. 1999. The role of structure and molecular properties of terpenoids in determining their antimicrobial activity. J. Flavour Fragr. 14:322332.

Gulcin I, MT Uguz, M Oktay, S Beydemir and OI Kufrevioglu. 2004. Evaluation of the antioksidan and antimicrobial activities of claysage (Salvia sclarea, L.). Turk I. Agric. 4:23-25.

Harborne JB. 1973. Phytochemical Method: Guide to Modern Analysis on Plant. 2nd Edition. Translated by Padmawinata, K. Dan I. Soediro. ITB, Bandung.

Hariana A. 2013. 262 Medicine Plants And The Benefits. Penebar Swadaya, Jakarta.

Haris MI. 2005. Chemical Composition, Physical Quality, Sensory and Alkaloid Residue in Bligon mutton fed papaya leaves with different level and termination time. Thesis. Graduate School. Faculty of Agriculture, University of Gadjah Mada, Yogyakarta.

Hartadi H, S Reksohadiprodjo, S Lebdosoekojo dan AD Tillman. 2005. Tabel Komposisi Pakan untuk Indonesia. Gadjah Mada University Press, Yogyakarta.

Kähkönen MP, J Heinämä ki, V Ollilainen, and $M$ Heinonen. 2003. Berry anthocyanins: isolation, identification and antioksidant activities. J. Sci Foot Agric. 83: 1403 - 1411.

Klita PT, GW Mathison, TW Fenton, dan RT Hardin. 1996. Effect of alfafa root saponin on digestive function in sheep. J. Anim. Sci. 74 (5): 1144-1156.

Kustantinah H Hartadi, R Utomo, A Agus, LM Yusiati, N Ngadiyono dan E Indarto. 2005. Conservation and utilization of cassava for bligon goats. Proceedings. Integrating Livestock-crop system to meet challenges of globalization. AHAT/BSAS International Confrence. Khon Kaen, Thailand. Pp. T42.

Makfoeld D. 2008. Dictionary of Food and Nutrition.. Penerbit Kanisius. Yogyakarta.

Makkar HPS. 2003. Effect and fate of tannins in ruminant animal. Adaptation to tannins and strategies to overcome detrimental effect of feeding tannin-rich feds. J. Small Rum. Res. 49 : $241-256$.

Makkar HPS, M. Bluemmel, NK Borowy, and K Becker. 1993. Gravimetric determination of tannins and their correlation with chemical and protein precipitation methods. J. Sci. Food Agric. 61: $161-165$.

McDonald P, RA Edward, and FJO Greenhalgh. 2002. Animal Nutrition. $6^{\text {th }}$ Ed. Longman Scientific \& Technical. John Willey \& Son. Inc., New York.

Min BR, SP Hart, D Miller, GM Tomita, E Loetz and T Sahlu. 2005. The effect of grazing forage containing condensed tannins on gastrointestinal parasite infection and milk composition in Angora does. J. Vet. Parasitol. 130: 105 - 113.

Mishra P. 2009. Isolation, spectroscopic characterization and molecular modeling studies of mixture of Curcuma longa, ginger and seeds of fenugreek. Int. J. of Pharm. Tech. Research. 1: 79 $-95$.

NSaewan, S. Koysomboon, and K Chantrapomma. 2011. Ati-tyrosinase and anti cancer activities of flavonoids from Blumea balsamivera DC. J. Med. Plants Research. 5 (6): $1018-1025$.

Nessa F, Z Ismail, N Mohamed, and MRHM Haris. 2004. Free radical-scavenging activity of organic extracts and of pure flavonoids of Blumea balsamifera DC leaves. Food Chemistry. 88: 243 252. 
Newbold CJ, B Lassalas, and JP Jouany. 1995. The importance of methaneogens associated with ciliate protozoa in ruminale methanee in vitro. Lett. Appl. Microbial. In Vitro, 21: 230-234

Nwinuka NM, GO Ibeh, and GI Ekeke. 2005. Proximate Composition And Levels of Some Toxicants In Four Commonly Consumed Spices. Journal of Applied Sciences \& Environmental Management, 9 (1): $150-155$.

Purwaningsih E. 2007. Cara Pembuatan Tahu dan Manfaat Kedelai. Ganeca Exact : Jakarta

Raaof AW, ZAE Al-Naqqash, ALM Jawad and SM Muhsan. 2013. Evaluation of the Activity of Crude Alkaloids Extracts of Zingiber officinale Roscoe., Thymus vulgaris L. and Acacia arabica L. as Coagulant Agent in Lab Mice. J. Biomedicine and Biotechnology. 1(2):11-16. http://www.iasj.net/iasj?func= fulltext\&ald=86971. (di akses pada tanggal 21 January 2016).

Ramakrishnan K And MRV Krishnan. 1994. Tannin classification, analysis and application. Ancient Science of Life. Vol No. XIII Nos. 3 \& 4:232 - 238.

Rao KN and SR Venkatachalam. 2000. Inhibition of dihydrofolate reductase and cell growth activity by the phenanthroindolizidine alkaloids pergularinine and tylophorinidine: the in vitro cytotoxicity of these plant alkaloids and their potential as antimicrobial and anticancer agents. Toxicol In Vitro. 14: 53 - 9.

Riahia L, M Elferchichib, H Ghazghazic, J Jebalid, S Ziadia, C Aouadhie, H Chogranif, Y Zaoualif, N Zoghlamia, and A Mlikia. 2013. Phytochemistry, antioxidant and antimicrobial activities of theessential oils of Mentha rotundifolia L. Tunisia Industrial Crops and Products. 49:883-889.

Robinson T. 1995. Organic Matter of Tall Plant. Translated by K. Padmawinata. ITB, Bandung.

Schuhmacher A, J Reichling, and P Schnitzler. 2003. Virucidal effect of peppermint oil on the enveloped herpes simplex virus type 1 and type 2 in vitro. Phytomedicine. 10:504-510.

Suryani CH. 2012. Optimasi Metode Ekstraksi Fenol dari Rimpang Jahe Emprit (Zingiber Officinalle Var. Rubrum). Agri Sains. 3(4):63-70. http://lppm.mercubuana-yogya.ac.id/
wcontent/uploads/2014/12/OPTIMASI-METODEEKSTRAKSI-FENOL-DARI-RIMPANG-JAHE-EMPRIT-

Zingiber-Officinalle-Var.-Rubrum.pdf. (Accessed on $11^{\text {th }}$ Januari 2016).

Susiarti S. 2000. Sembung (Blumea balsamifera (L.) $D C$.). In H. Sutarno and S. Atmowidjojo (Editor). Potensi dan Cara Pemanfaatan Bahan Tanaman Obat. Prosea Indonesia-Yayasan Prosea, Bogor.

Ultee A, EPW Kets, And J Smid. 1999. Mechanisms of action of carvacrol on the food-borne pathogen Bacillus cereus. Appl. Environ. Microbiol. 65:4606-4610. http://aem.asm.org /content/65/10/4606. (Accessed on $4^{\text {th }}$ August 2015).

Viola E, Zimbardi F, Cardinale M, Cardinale G, Braccio G, and Gambacorta E. 2008. Processing cereal straws by steam explosion in a pilot plant to enhance digestibility in ruminants. Bioresource Technoly. 99(4):681-689.

Wallace RJ, L Arthaud, and CJ Newbold. 1994. Influence of Yucca shidigera extract on ruminal ammonia concentrations and ruminal microorganisms. Appl. Environ. Microbiol. 60: $1762-1767$.

Winarno FG. 2006. Food Chemical and Nutrition. PT Gramedia Pustaka Utama, Jakarta.

Wink M. 2015. Modes of Action of Herbal Medicines and Plant Secondary Metabolites, a review. Medicines. 2:251-286. www.mdpi.com/journal /medicines (Accessed on 11 January, 2016).

Wohlmuth H., D.N. Leach, M.K. Smith, and S.P. Myers. 2005. Gingerol content of diploid and tetraploid clones of ginger (Zingiber officinale Roscoe). J. Agric. Food Chem. $53: 5772$ - 5778.

Xu SB, WF Chen, HQ Liang, YC Lin, YJ Deng, and KH Long. 1993. Protective action of blumeatin against experimental liver injuries. Zhongguo Yao Li Xue Bao Jul. 14(4):376-378. [http://www.ncbi.nlm.nih.gov/Entrez/query.fcgi? cmd =Retrieve\&db=PubMed \& listuids = 8249641\&dopt $=$ Abstrac. (Accessed on 12 Agustus 2014).

Zain M. 2009. Substitution of field grass with ammoniated cocoa husk in local feed ration. Jurnal Media Peternakan 32:47-52. 